\title{
Q.
QNEEN'S
UNIVERSITY
BELFAST
}

\section{Authority, Nationality, and Minorities}

Schwartz, A. (2015). Authority, Nationality, and Minorities. Ratio Juris, 28(3), 354-371.

https://doi.org/10.1111/raju.12087

\section{Published in:}

Ratio Juris

\section{Document Version:}

Peer reviewed version

\section{Queen's University Belfast - Research Portal:}

Link to publication record in Queen's University Belfast Research Portal

\section{Publisher rights}

(C) 2015 The Author. Ratio Juris $\odot 2015$ John Wiley \& Sons Ltd This is the peer reviewed version of the following article: Schwartz, A. (2015), Authority, Nationality, and Minorities. Ratio Juris, 28: 354-371, which has been published in final form at

$\mathrm{http}: / /$ onlinelibrary.wiley.com/doi/10.1111/raju.12087/abstract. This article may be used for non-commercial purposes in accordance with Wiley Terms and Conditions for Self-Archiving.

\section{General rights}

Copyright for the publications made accessible via the Queen's University Belfast Research Portal is retained by the author(s) and / or other copyright owners and it is a condition of accessing these publications that users recognise and abide by the legal requirements associated with these rights.

\section{Take down policy}

The Research Portal is Queen's institutional repository that provides access to Queen's research output. Every effort has been made to ensure that content in the Research Portal does not infringe any person's rights, or applicable UK laws. If you discover content in the Research Portal that you believe breaches copyright or violates any law, please contact openaccess@qub.ac.uk. 


\title{
Authority, Nationality, and Minorities
}

\begin{abstract}
ALEX SCHWARTZ*
Abstract. Prominent normative theories for accommodating minority national groups appeal to the value of national cultures and/or the psychology of group recognition. This article hopes to show that an argument from political authority provides a better justification. Building on Joseph Raz's theory of authority, the article argues that members of minority national groups are disadvantaged relative to their majority counterparts under standard democratic institutions; such institutions do not provide minority national groups with comparable access to the conditions for legitimate political authority. Constitutional arrangements for accommodating minority national groups - such as territorial selfgovernment or power-sharing - are justified then in so far as they might ameliorate this disadvantage.
\end{abstract}

\section{Introduction}

At least since the 19th century, political authority has commonly been exercised on behalf of nations. Modern states typically purport to be "nation-states" whose regimes derive their legitimacy, not from divine or dynastic right, but from their relationship to the particular national communities they govern and serve. Nationhood is also one of the grounds upon which the legitimacy of political authority is frequently challenged. Separatist movements assert that the prevailing state has no right to rule their national communities, at least not without their collective consent. Sub-state nationalists who seek greater self-determination within existing state boundaries claim that the state is home to multiple national demoi, each of which is entitled to self-government and some measure of control over constitutional change (See Keating, 2001; and Tierney, 2004).

Despite the apparently pervasive connection between nationalism and questions of political authority, normative political theorists have generally appealed to other values or concerns when arguing the case for accommodating minority nationalism. Broadly speaking, these arguments cluster into two types: those which appeal to the importance of national cultures as contexts of meaningful choice and those which appeal to the psychology of group recognition. I hope to show here that the connection between

\footnotetext{
* I am especially grateful to David Miller for his guidance and support while I was working on this material as a guest of the Centre for the Study of Social Justice at the University of Oxford (Michaelmas Term, 2012). I would also like to thank the participants of the Nuffield College Political Theory Workshop (Michaelmas Term, 2012), Les Green, Andrew Lister, David Miller, Margaret Moore, and Zoran Oklopcic for insightful and constructive comments on drafts of this work at various stages in its development.
} 
nationality and political authority yields a better theoretical basis for accommodating minority nationalism than either of these arguments.

My argument takes its inspiration from Joseph Raz's seminal work on authority. Raz proposes (almost as an afterthought to his main theory) that identification with one's community provides a reason to identify with the community's laws and government and, consequently, a reason to accept the putative authority of those laws and government (see Raz 1979, 258-61; 1984, 154-55; 1998, 54-5 and 97-9). Building on this often neglected aspect of Raz's theory, I argue that members of minority national groups are disadvantaged relative to their majority counterparts under standard democratic institutions; such institutions do not provide minority national groups with comparable access to the conditions for legitimate authority. Special constitutional arrangements for accommodating minority nationalism can therefore be justified in so far as they might ameliorate this disadvantage.

The argument proceeds in three parts. In the first part, I outline the main theories for accommodating minority national groups, highlight their limitations, and explain why the problem of political authority provides a more promising focus. In the second part, I take up Raz's idea that nationality might provide a normative reason for accepting authority and consider the conditions under which such acceptance would be justified. As I explain, the normative force of nationality with respect to political authority depends, amongst other things, on a sufficiently democratic system of government. Despite this important qualification, I go on to argue that nationality plays a crucial role for political authority in modern democracies; it provides a particularly salient solution to the problem of the personal scope of authority, i.e. the "boundary problem" of the demos, a problem that is logically prior to the operation and democratic genesis of law. In the third and final part, I return to the question of accommodating minority national groups. I explain how minority national groups are disadvantaged under standard democratic systems of government (in terms of their relationship with political authority) and how special counter-majoritarian arrangements (such as territorial autonomy or consociational power-sharing) might remedy this disadvantage.

\section{Culture and Recognition}


As noted above, the leading normative arguments for the accommodation of minority national groups tend to follow two broad patterns which, for lack of more elegant terms, I will call the "culture argument" and the "recognition argument". Variants of the culture argument justify the accommodation of minority national groups in terms of the protection of cultural contexts of choice. The most influential proponent of this line of argument is Will Kymlicka. Kymlicka ties the accommodation of minority national groups to the value of what he calls “societal cultures” (Kymlicka 1995, 75). A societal culture, he explains, is "[a] culture which provides its members with meaningful ways of life across the range of human activities, including social, educational, religious, recreational, and economic life, encompassing both public and private spheres” (Kymlicka 1995, 75). Kymlicka argues that societal cultures are vital to human freedom: "freedom involves making choices amongst various options, and our societal culture not only provides these options, but also makes them meaningful to us” (Kymlicka 1995, 83). Territorial self-government, language rights, and greater influence over immigration policies are justified then as means to maintain socio-cultural distinctiveness against majoritarian pressures to assimilate (Kymlicka 1995, 85). Notice that the culture argument presumes that the national minority group possesses two objective characteristics: (1) societal or cultural distinctiveness and (2) territorial concentration. Societal or cultural distinctiveness provides the normative justification for some kind of accommodation; territorial concentration creates the potential for the remedy of territorial self-government (see Tierney 2004, 32).

One limitation of the culture argument is that it is relatively easy to point to cases of minority national groups that are neither territorially concentrated nor endowed with a distinct societal culture (at least not of the sort Kymlicka has in mind). Generally speaking, where a majority and minority group have been living for some time intermingled within the same territory, under the same institutions of government, and sharing many of the same public spaces (and perhaps also speaking the same language), it will no longer make much sense to talk in terms of distinct societal or cultural contexts. This is the case, for example, in Northern Ireland; Irish nationalists and British unionists are territorially intermingled, overwhelmingly speak English as a first language, and share many other cultural traits. If such cases were merely marginal cases, the culture argument might yet provide a general answer to the question of accommodation. But the cases of minority 
national groups in places like Northern Ireland (or Bosnia) are, I think, fairly central cases. In any event, they show that societal or cultural distinctiveness (in Kymlicka's sense) is not a "crucial or even necessary element" in the formation of distinct national identities or the emergence of ethno-national conflict (Moore 2001, 14).

A further problem with the culture argument is that it does not actually justify minority self-government per se. Rather, the argument justifies a set of policies designed to insulate minority national groups from cultural assimilation, and self-government is presumed to be the most effective way to deliver these policies. But there is no reason, strictly speaking, why such policies cannot be imposed paternalistically by the state on behalf of a national minority. If, for example, the Spanish state was committed to the promotion and protection of Catalonia's distinctive societal culture, the culture argument could presumably be satisfied without having to actually devolve any powers to Catalonia itself. In other words, pursuant to the culture argument, minority self-government is of only instrumental and, ultimately, contingent value. This feature of the argument runs counter to the claims of minority national groups who see self-government as en end in itself. This discrepancy is not necessarily fatal to the culture argument; an argument for accommodating minority national groups need not correspond to the self-understanding of actual minority nationalists. Still, other things being equal, an argument that came closer to capturing the nature and extent of the claims made by minority nationalists would, I think, be that much more satisfying.

In contrast to the culture argument, variants of the recognition argument justify the accommodation of minority national groups in terms of the importance of group recognition for the individual's sense of self-worth. According to this line of argument, individual identity is (at least partly) constituted by one's membership and participation in a given national community. Consequently, the recognition (or mis-recognition) of the national community to which one belongs is said to have a critical impact on one's basic sense of self-worth. As Charles Taylor puts it, identity is “dialogical” (Taylor 1994, 33). Our sense of who we are as individuals is always, to some extent, formed, sustained, and revised in "communication with significant others” (Taylor 1994, 33). In this way, social roles and group affiliations - including membership in a national community - are constitutive of the individual. Because individual identity is "bound up” with one’s sense 
of belonging to certain groups, our "self-respect is affected by the esteem in which these groups are held” (Margalit and Raz, 449). On this view, the accommodation of minority national groups is justified as part and parcel of giving members of minority national groups their due recognition.

The recognition argument has two important weaknesses. First of all, nationality is not the only aspect of a person's identity, nor is it necessarily the most important or meaningful aspect of identity. Ethnicity, religion, or sexual orientation are all aspects of identity which, depending on the individual, may be equally or more significant to her. So the recognition argument does not tell us why minority national groups are owed some special accommodation that these other groups are not. Second, the psychological assumptions of the recognition argument are difficult to substantiate empirically. Indeed, there is some evidence to suggest that there is no predictable relationship between the public status of national groups and the self-esteem of their members (see Spinner-Halev and Theiss-Morse 2003).

An argument from political authority hopes to succeed where these arguments fail. Nationality can be constructed in various ways. Sometimes the nation is imagined as an ethnic or cultural community sharing a common language or some set of narratives and traditions. The nation can also be imagined in more "civic" terms, as a political community defined primarily by territory or public institutions. Often nationality draws on each of these sources to varying degrees. There is, however, one thing that appears to remain constant in the general grammar of nationality. However nations may be imagined, they are always imagined as "sovereign" communities (Anderson 2006, 6). This is not to say that all national groups are necessarily endowed with or demand their own sovereign state. Rather, the point is that the grammar of nationality takes national groups to be actual or potentially self-determining. As Bernard Yack has recently put it, the common denominator in all instances of nationalism is a "nationalist principle of political legitimacy" according to which national groups should, in one way or another, be the "masters" of the political institutions that govern them (Yack 2012, 122-23; see also Brubaker 2004).

Because the connection to political authority is so basic to the logic of nationality, an argument from political authority can, in contrast to the culture argument, provide a more generalizable justification for accommodating minority national groups. 
Furthermore, in contrast to the recognition argument, an argument from political authority identifies something special that distinguishes the claims of minority national groups from those made by other minorities. That being said, simply noting the connection between nationality and political authority does not itself yield a normative argument. It remains to be seen whether and to what extent the nationalist principle of political legitimacy can be vindicated by normative theory. To that end, let us turn to consider the question of political authority in more detail.

\section{Nationality and Political Authority}

\subsection{Razian3.1 Razian Authority}

Joseph Raz's theory of authority has been described as "the richest and most fertile account we have" (Waldron 2003, 69). After several decades, the theory continues to stimulate debate (see e.g. Darwall 2010; Hershovitz 2010; Martin 2010; Rundle 2012; and Sherman 2010). As it happens, Raz's work also helps to illuminate the implications of nationality for political authority (although this aspect of his theory is usually overlooked).

On Raz's view, to accept a directive as genuinely authoritative is to treat it as a special kind of reason for action, one that is both content-independent - because the directive is meant to be a reason for action regardless of its substantive merits - and preemptive - because the directive is meant to overrule, rather than participate, in the balance of other reasons that might apply in a given case to the addressee (Raz 1988, 35 and 42). Accordingly, the central proposition of Raz's theory of authority - what he calls "the normal justification thesis" ("NJT") - is intended to define the circumstances in which we have sufficiently good reasons to treat a putative authority as genuinely authoritative (Raz 1988, 53).

Pursuant to NJT, the legitimacy of any practical authority (political or otherwise) depends on its ability to "serve" its addressees by guiding their actions in accordance with right reason (Raz 1988, 46). A putative authority is legitimate then where the addressee is "more likely to act successfully for the reasons which apply to him than if he does not subject himself to its authority” (Raz 1988, 71). But because people's capacity for right reason varies, the question of authority "depends on the person over whom authority 
is supposed to be exercised: his knowledge, strength of will, his reliability in various aspects of life, and on the government in question” (Raz 1988, 73). It is therefore extremely unlikely, according to Raz, that any state anywhere actually possesses the universal legitimate political authority it claims to possess (Raz 1988, 78). Rather, political authority is likely to be legitimate "to various degrees regarding different people" (Raz 1988, 104).

To the extent that NJT only yields a patchwork and piecemeal result, Raz proposes that communal identification can play a role in extending the legitimacy of political authority. As he explains, in so far as the government and legislators are official organs of the community, respect for the law is a natural way of expressing one's sense of communal solidarity. Assuming then that identification with the community - the feeling "of belonging and of sharing in its collective life" - is a morally worthwhile attitude (Raz 1988, 91), those who are so moved have good reason to treat their community's laws and government as authoritative ( $\operatorname{Raz} 1979,250)$. Reasons of communal identification can therefore be decisive where the standard calculus of NJT is not (see Raz 2006, 1028). Where the requirements of right reason are otherwise ambiguous or obscure, communal identification gives the individual a reason to defer to her community's laws and government.

Now I think it is fair to say that Raz's reflections on identification with the community are primarily about national identification; Raz is talking about the authority of the state and nationality is, for complex historical reasons, the mode of communal identification that is most closely associated with states (see Gellner 1983; Calhoun 2007, 148-54; and Yack 2001). But Raz's reflections on communal identification and political authority are relatively brief and they raise a number of questions that warrant a more extended treatment. First, if reasons of nationality are genuine normative reasons, how much force do they have for the problem of political authority relative to other normative reasons that might matter? Second, if nationality (as a mode of collective identity) does play a role in political authority, how important a role is it?; is there anything special about nationality-based reasons for the legitimacy of political authority? Finally, if nationality is especially important for the problem of political authority, what are the practical implications of this conclusion for divided polities where people lack a common national identification? 


\subsection{The Normative Force of Nationality}

A full defence of national solidarity would take us far beyond the scope of the present discussion. For the sake of the argument here, the reader need only accept at the outset that nationality is not necessarily evil or irrational. This is not to deny that nationality can be and has been the driving force behind a great many bad things. But in addition to the various evils it might motivate, nationality might also inspire people to do great things, to participate in redistributive social welfare schemes, to compose epic poetry, to build beautiful monuments, and so on. In this way nationality is similar to romantic love; it is a motivation that may inspire a range of actions, some of which are laudable while others are shameful. The question I want to address here is how, in addition to being a motivating reason, nationality might also be a normative reason for accepting authority in the way that Raz's theory suggests.

We might distinguish between motivating reasons and normative reasons in the following way: motivating reasons are reasons which are "internal” to us in that they derive from our subjective beliefs and desires while normative reasons are "external" to us in that they apply to us (or should) regardless of our beliefs and desires (see Parfit 1997). Where

our motivational reasons do not correspond to normative reasons they are merely “explanatory”, i.e. they explain why we behave or think a certain way but say nothing about how we ought to behave or think (see Raz 2011, ch. 2). Conversely, where normative reasons do motivate us to act or think accordingly, the reasons in question are both explanatory and normative. Let us accept then that the force of some normative reasons may be totally external to our subjective beliefs and desires. Presumably, for example, there are normative reasons not to steal or murder, regardless of whether or not they are known to us. From our perspective, as agents, all that matters is that these normative reasons are knowable - i.e. that they can be grasped as a reason - and so could become motivational reasons if we were sufficiently morally astute. But might there be some subset of normative reasons which would not exist but for certain motivations which we may or may not have in the first place?

Consider the way friendship might create normative reasons. Friendship is, in the 
first place, a matter of affect. Accordingly, it generates motivating reasons to spend time with our friends, to assist them when they are in need and so on. But we experience these motivations as normative reasons - we feel as though we ought to pay our friends a visit when they are unwell or getting over a bad breakup or experiencing some other personal difficulty. If we fail to do so, a friend might question whether or not we are really such a good friend to her. Are we mistaken to experience friendship in this way? I do not think so. ${ }^{1}$ Friendship has moral value; our lives are richer and more meaningful for it. Reasons of friendship have normative force then in so far as they help to sustain that value. These reasons would not apply to us were we not friends and so, in this sense, our friendship generates them.

My claim then is that nationality, like friendship, generates normative reasons which would not exist but for the underlying motivational reasons. Like friendship, the affective bonds of national community have value for their members and so, like friendship, may generate normative reasons that support this value. The precise content of these reasons what they specifically ask of us - is contingent on how nationality is culturally constructed. Just as norms of friendship or filial piety may vary across cultures, I doubt that there is any eternal and universal truth about how one ought to express one's sense of national solidarity (see Miller 1995, 68-9). But given the way in which nationality is constructed in our world today, one of the normative reasons that would seem to follow from nationality is a reason to accept the authority of the institutions which speak on behalf of one's national community. In doing so, one expresses one's solidarity with one's co-nationals in support of a common national political enterprise and thereby helps to sustain that enterprise.

That being said, we have to be careful here not to attribute too much normative force to reasons of nationality. This is one of the hazards of so-called theories of "associative political obligation” (see e.g. Dworkin 1986, 195-215; Gilbert 2006; Horton 1992; Miller 1995, ch. 3; and Tamir 1995, ch. 5). Theories of associative political obligation, often drawing on the analogy with friendship or the family, maintain that membership in the political community is the ultimate ground of political authority. As Ronald Dworkin puts

\footnotetext{
${ }^{1}$ There is of course a very profound question here about the extent to which the grounds of ethical or moral truth may be, at least in part, particularistic and therefore linked to ethical or moral sentiment. I have neither the space nor the philosophical resources to defend this view at any great length here. For a like-minded and more detailed argument for ethical particularism as it applies to nationality, see Miller 1995, ch. 3.
} 
it, the legitimacy of political authority is to be based, "not in the hard terrain of contracts or duties of justice or obligations of fair play that might hold among strangers, where philosophers have hoped to find it, but in the more fertile ground of fraternity, community, and their attendant obligations” (Dworkin 1986, 206).

Typically, theories of associative political obligation attribute free-standing moral force to membership such that all members have at least a prima facie duty to obey the community's leaders and laws. Moreover, these obligations of association are supposed to hold whether or not one has voluntarily entered the community or agreed to assume the obligations in question. Following A. John Simmons, let us call these two theses, respectively, the "normative independence thesis" and the "anti-voluntarism thesis" (Simmons 1996, 248 and 252). Note that the second thesis is really an extension of the first; if the obligations in question were contingent upon having been voluntarily assumed then it would be the moral force of consent, and not the fact of membership, that did the normative work.

A strict adherence to these two theses gives too much normative force to national membership itself. First of all, the normative independence thesis can lead to some strange and dubious conclusions. Yael Tamir, for example, ends up allowing that even morally suspect associations, such as the Mafia, can generate genuine moral obligations for their members (Tamir 1995, 101). This conclusion seems just as problematic when applied to political communities. Governments are often oppressive and unjust. If the community as a whole endorses the evils of its government, what moral reason can there be to defer to them? In the alternative, as Raz points out, if the community does not endorse the evils of its government, then presumably disobedience or even violent resistance would be the morally appropriate way to express solidarity with one’s fellows (Raz 1988, 92). The obvious problem of evil regimes aside, there is still a more general danger that identification with the community, and a consequent acceptance of authority, will be based on a kind of false consciousness; people may be motivated by blind patriotism or manipulated by propaganda to identify with their government against their own better interests (Simmons 1996, 264). ${ }^{2}$

\footnotetext{
${ }^{2}$ In response to such concerns, proponents of associative obligations might concede that associative obligations are only possible for sufficiently good or egalitarian communities (see e.g. Dworkin 1986, 214).
} 
The anti-voluntarism thesis also creates problems for theories of associative political obligation. The moral significance of national membership can be analysed in objective or subjective terms (see Renzo 2012; and Van der Vossen 2011). In objective terms, it is the fact of membership in the political community, i.e. citizenship, which would matter. On this view, rights and duties are constitutive of the concept of citizenship and so political obligations are simply part of what it means to be a member of a political community. But the normative force of legal rights and duties is precisely what is at issue in the problem of political authority; to point to these as if they justify themselves is to beg the question. Thus, proponents of associative obligation are often compelled to locate the moral significance of membership in the subjective feeling of belonging (see e.g. Horton 1992). This strategy has its limits. The subjective sense of membership in the community is, at least in part, a matter of individual volition. Although an individual may not be able to pinpoint a specific moment in time when she first "choses" to identify with her national community, she can always decide to renounce that identification (Renzo 2012; cf. Miller 1995, 60). Indeed, we can imagine all kinds of good reasons why she might (think of Nazi Germany). She may also prioritize other sources of identity (class, religion, etc.) which can be just as meaningful as national identification. If we admonish such a person on the grounds that she has a duty to identify with her national community (or primarily with her national community) simply because it is her community then we presuppose, rather than justify, obligations based on membership. In other words, although one may be born into a particular national community, there is no moral duty to ascribe to the national identity in question (see Raz 1998, 99).

In addition to the problems noted above, there is another and perhaps more fundamental difficulty with treating membership in a national community as a conclusive answer to the problem of political authority. Locating legitimate authority in group membership of any kind only reproduces the problem of authority at another level. For any group, one can always ask: by what authority can some individual or institution claim to speak or act on behalf of the collective?

\footnotetext{
But this kind of concession, although justified and probably necessary, compromises the normative independence thesis and, at the very least, raises the suspicion that some other normative reason, say justice or equality, might be doing the real work.
} 
It is important to appreciate how the circumstances of large-scale modern political communities set the terms of this question. Imagine a hypothetical small-scale traditional community in which there is a wide-ranging consensus about questions of common concern. In such a community, some individual (or set of individuals) might be empowered to make decisions on behalf of the group. Assuming a certain level of fluency with the group's shared values, they might govern prudently and in accordance with those values. In such a case, we can grant that members of the community might have sufficient grounds for seeing these governing decisions as the group's decisions. But nothing like this is plausible in modern large-scale polities where there is likely to be no broad substantive consensus for the law or policies of the government to reflect or embody. This is not to deny that at various times in modern history certain politicians have professed to be the "authentic" personification of the "General Will". Dictators typically claim this kind of caesaristic authority. But while masses of people are occasionally swayed by such claims, clearly they ought not to be. Any automatic or thoughtless submission to someone who professes to speak for the group cannot be consistent with rational agency and so (at least on the Razian account I endorse here) cannot be the basis for legitimate authority. Consequently, there can be no easy pre-procedural "truth" about what a modern political community's interests and values are. For the most part, shared values and interests can only be imputed to a modern pluralistic polity as the output of its collective decisionmaking processes. Thus, if nationality is to have any relevance for political authority, it will be because procedures of one kind or another allow us to justifiably transfer our identification with the community to the laws or policies of the government more generally.

Here I think democracy, understood broadly as a system of representative government featuring periodic and popular elections, is probably the only form of government that can allow us to justifiably translate communal identity into acceptance of authority (cf. Miller 2007, 128). Democracy gives everyone (or at least those who can vote) a formally equal opportunity to influence political decisions, albeit indirectly through elected representatives (see Waldron 1995; Christiano 2004; and Sadurski 2008). This makes democracy special. Many organizational structures (including dictatorship) can select a particular course of action to be undertaken and attributed to a group, but only democratic procedures give all members of the group a rational basis to see a decision as 
that which they, as a group, have chosen. Obviously, democratic systems are often perverted by powerful interests that compromise this sense of collective agency. But, generally speaking, the more democratic the system of government, the more reason we have to attribute political decisions to the group and, consequently, the more normative force nationality will have for political authority. ${ }^{3}$ In any case, a shared nationality can provide a general reason to accept the putative authority of the laws and government only if the laws and government are appropriately representative of the community in question and, given the circumstances of modern pluralistic societies, this "representativeness" would seem to require some measure of popular democratic control.

To sum up the argument thus far, political authority is best understood as a complex question for which many normative reasons might be relevant. Nationality is one of those reasons; when coupled with a sufficiently democratic context, a shared nationality gives us reason to identify with (and consequently reason to accept the authority of) the laws and government of our polity. But, as we have seen, other reasons - reasons of justice, institutional competence, or procedural fairness - also matter. In some cases, as with wicked regimes, these other reasons may vitiate the normative force of nationality altogether. Nevertheless, as I will argue below, reasons of nationality can sometimes play a crucial role in legitimate political authority.

\subsection{The Importance of Nationality for Political Authority}

Let us return for the moment to Raz's NJT. In the absence of reasons of nationality, there may yet be a good deal of legitimate authority that derives from simple NJT reasons alone. For one thing, I take it that the usual NJT reasons that legitimate the bulk of the law of contract, tort law, or traffic regulations hold regardless of our nationality or the nationality of those who make the law for us. In such cases, authority is legitimate in virtue of its relative expertise and/or its capacity to create arbitrary conventions that help us to secure goals which we all have reason to pursue but "for which social co-ordination is necessary or helpful” (Raz 1988, 100). Thus, given enough information, we can imagine that NJT

\footnotetext{
${ }^{3}$ A truly "direct" democracy in which every decision was taken by popular vote would achieve this effect of collective agency more perfectly, but I take it that such a scheme is generally unworkable for large-scale polities.
} 
will yield "right" answers about which all reasonable people would agree. There is no need to activate reasons of nationality in such cases.

But questions of common concern are not limited to questions of arbitrary convention or relative expertise. Many matters - like social welfare, immigration law, or reproductive rights - turn on contested conceptions of the good and/or the right. These are not matters of arbitrary convention, nor will information or expertise uncover a universally accessible standard of wisdom about them. This is not to say that there are no right answers. Rather, the problem we face is that there is no way to know when we have arrived at the right answer. In such cases, simple NJT reasons cannot solve the problem of authority for us (see Waldron 1995, 2197).

Raz's critics have seized on this issue. They argue that a theory of political authority should explain how authoritative decision-making is possible amongst people who are likely to disagree about what laws or policies satisfy the conditions of NJT and so, the critics claim, Raz wrongly neglects the importance of democratic procedures (see Christiano 2004; and Hershovitz 2003; 2011). I think Raz's critics are right to point to the importance of democracy for political authority. For one thing, as we saw earlier, the normative force of nationality would seem to depend on some set of democratic procedures that justify our identification with political authority. But perhaps democratic procedures alone have sufficient normative force to solve the problem of political authority without reference to some other set of normative reasons. If democratic procedures can provide a fair and egalitarian way of making decisions amidst deep disagreement, why should nationality matter at all for political authority?

The answer to this question turns on the problem of the personal scope of political authority. Whatever their virtues for collective decision-making, "democratic methods themselves are inadequate to establish the bounds of the collectivity, whose existence democratic theory simply presupposes” (Whelan 1983, 22). This limitation is sometimes referred to as the "boundary problem" in democratic theory (See Simmons 2013; Miller 2009; Näsström 2007; and Whelan 1983). Political theorists have responded to the boundary problem in several ways, usually focusing on how the demos should ideally be delineated. Some resolve the problem by asserting that the boundaries of political communities are morally arbitrary (see Näsström 2007, 52). Others, such as David Miller, 
argue that democracy works better where the boundaries of political communities match the boundaries of national communities as far as is practical (see Miller 2007). Still others would expand the boundaries of the democratic franchise according to the scope of those whose interests are affected by the political decisions or institutions in question (Goodin 2007). But the boundary problem is not just about how to delineate the ideal demos. The problem also has implications for those who find themselves already included within existing boundaries. Here democratic procedures alone cannot solve the problem of why the law and government, whatever their democratic credentials, should have authority over the particular set of people they purport to govern. Let me explain with an analogy.

Suppose a group of people have voluntarily come together to start a jazz appreciation society in their town.1 Once a month, they pool some of their resources to bring in noted jazz artists to play concerts. The members of the society do not always agree about which artists to bring in; their preferences vary. They settle their disagreements by simple majority vote. Now suppose you are a resident of the town (who has not yet joined the society) and the society comes to you and informs you that everyone in the town is automatically a member of the jazz society. They insist that you are therefore required by the society's constitution to contribute to the fund. I imagine that you might protest, especially if you do not like jazz or if you are quite sure that your jazz preferences would be in the minority. The fact that the society's decisions are made democratically among all affected interests would not be of much consolation. Regardless of how their decisionmaking procedures might be structured, you would insist that you do not want your interests to be affected by the society's decisions, that the society has no authority to impose membership and its associated fees on you in the first place (see Simmons 2013, 339-40). You might argue that only your consent to membership could give the society's decisions any legitimate authority over you.

I trust that the reader can see that this scenario is an iteration of the boundary problem, albeit on a much smaller scale. As the scenario suggests, consent is the way in which the boundary problem is typically solved for smaller associations of this kind. We join voluntary associations and we assume the duties and rights that follow. Consent does not necessarily solve the problem of authority within those associations - they still need to devise their own internal decision-making procedures. But consent does solve the problem 
of the personal scope of the association's putative authority. The situation is very different with states. States do not generally provide their members with meaningful opportunities to consent to their inclusion within the scope of political authority (see Green 1988, 15887). Most of us are born into extant political communities in which we live most of our lives. We cannot simply leave, at least not without great personal cost, if it turns out that we do not want to be subject to the state's laws and government.

Does the boundary problem therefore undermine the putative legitimacy of political authority? Not entirely. As we saw earlier, many matters of political authority are imperatives for which NJT reasons will suffice. Thus, regardless of the boundary problem, the state can subject us to laws against murder and theft because those acts are unquestionably bad. Likewise, assuming that the state provides and maintains roads, it is an imperative of right reason that there be some common set of traffic laws. Similarly, the state might legitimately regulate the products we buy and sell for reasons of public health and safety. However, as we also saw earlier, some matters are more like the preferences of our jazz aficionados; they turn on contested values and preferences. Such matters are not simply matters of obvious moral truth, arbitrary convention, or relative expertise. Reasonable people will disagree. Democratic procedures provide a way of making decisions amidst this kind of disagreement, but they cannot legitimate the personal scope of the authority in question. Here the boundary problem looms large.

This is where nationality can play a crucial role. For most of us, the boundary problem is not a problem. Typically, we are born into a national community that corresponds with the political boundaries and democratic franchise of the state. We are socialized into these demoi and develop an affinity for our co-nationals and a corresponding sense of loyalty to the community’s public institutions. In short, most of us do not experience any boundary problem because our nationality has already solved the problem for us. If, as argued earlier, reasons of nationality are in fact genuine normative reasons, then most of us will also have reason to accept the boundaries of our demos together with the outcome of its (presumably democratic) political processes.

This is not to say that all people are necessarily aware of the special role that nationality might play in the legitimacy of political authority. For one thing, nationalitybased reasons for accepting political authority will not apply to everyone. Some people 
may eschew bounded identities altogether and prefer to think of themselves in purely cosmopolitan terms. Even among people who do identify with a particular national community, nationality may play only a minor part in how they think about their relationship to political authority. But the force of nationality-based reasons for accepting authority does not require that these reasons apply to everyone, nor does it require that these reasons are actually known by those to whom they apply. As with the reasons that figure in NJT, what matters is that the reasons in question are knowable and can therefore be activated upon reflection (see Raz 2007, 1025).

\section{Accommodating Minority National Groups}

If I am right that, at least for some people some of the time, nationality plays a crucial role in political authority, there is also at least one class of people who will predictably lack nationality-based reasons to identify with the government and its laws: members of minority national groups, i.e. those who do not happen to identify with the conception of national community subscribed to by the majority of the population and reflected in the state's boundaries and institutions. ${ }^{4}$ All the same, the state claims virtually unlimited authority over both sets of people across virtually every aspect of life. The question for this final section then is whether or not this disparity has any practical implications for how public power ought to be structured in nationally divided societies.

First of all, it should be noted that simply being in the minority with respect to democratic decision-making is not necessarily a problem for political authority. As Jeremy Waldron explains, there is an important difference between what he calls the "decisional" minority and what he calls the "topical" minority (the decisional minority being those who do not support a particular decision; the topical minority being those who are specifically impacted by the decision) (Waldron 2006, 1397). If one finds oneself in a decisional minority one merely holds an opinion that was insufficiently popular to prevail. This experience is not necessarily oppressive, even if one is also a member of the "topical" minority who is impacted by the decision in question (Waldron 2006, 1398). According to

\footnotetext{
${ }^{4}$ For simplicity's sake, I have bracketed the possibility of what Michael Keating calls 'plurinationalism', i.e. that 'more than one national identity can pertain to a single group or even an individual' (Keating 2001, 27). I suspect that even those who have plurinational identities will nevertheless tend to prioritize a single nationality with respect to some matters, especially when political authority over those matters is contested.
} 
Waldron, majority rule is only a real danger where topical minorities are consistently aligned with decisional minorities. As he sees it, the problem in such cases is not so much that one group of people is perpetually the minority; the problem is that the minority is especially vulnerable to abuse (Waldron 2006, 1403).

This relatively optimistic view of majority rule trades on the assumptions that (1) politics is mostly about the competing interests and opinions of individuals and (2) that these preferences, however firmly held, are at least susceptible to the force of argument (Waldron 2006, 1361). In this way the blunt nature of majoritarian preference aggregation is offset by the possibility that any person in the minority today could, in theory, find herself in the majority tomorrow.

These assumptions are problematic in any context, but especially so in a society divided along national lines. The assumption that politics is primarily about individual preferences might be plausible in small direct democracies, but in large-scale representative democracies it is not. Elected officials do not act as direct proxies for specific individuals. It is only because the preferences and interests of assorted individuals coalesce into intelligible clusters that the concept of representation is intelligible: "[t]he concept of 'representation' necessarily applies to groups: groups of voters elect representatives, individual voters do not". ${ }^{5}$ Moreover, political preferences cannot always be extricated from preferences about who governs and preferences about who governs are not always amenable to shifting opinion or debate. In divided societies the "politics of ideas" is frequently eclipsed by a "politics of presence" (Phillips 1995). In such cases, political preferences cluster into distinct "group-perspectives" and these extend to the question of who should speak for the group (Phillips 1995, 6). In so far as such preferences are anchored in socially structured group-perspectives, they cannot be easily exchanged for one another according to the force of argument. A British unionist in Northern Ireland, for example, cannot be converted to Irish nationalism in the same way that some lifelong American Democrats were persuaded to vote for Ronald Reagan. When a polity becomes politically polarized in this way elections predictably proceed "like a census" (Moore 2001). And so, far from facilitating the equal opportunity of everyone to advance his or

\footnotetext{
${ }^{5}$ Davis v. Bandemer, 478 U.S. 109, 167 (1986) (Powell, J., concurring and dissenting).
} 
her interests, majoritarian democracy may allow one group of people to indefinitely prevail over others.

Of course, there are other groups besides nationalist minorities who might also be indefinitely in a decisional minority. Libertarians, religious fundamentalists, and Marxists, to name only a few, may also find themselves consistently outvoted and unable to realize their political preferences. But the disparity between minority national groups and these other groups is not a function of their relative voting power. The disparity consists in the background reasons for accepting authority that are accessible regardless of voting power. Libertarians, religious fundamentalists, and Marxists, assuming they belong to the national majority, are not categorically denied access to reasons of nationality. French libertarians, for example, are likely to disagree with the bulk of the law of taxation. But they are no less French for that reason. ${ }^{6}$ And so, assuming a democratic context, French libertarians have reasons of nationality to accept the authority of the government and law when other reasons fail. They can accept these decisions as the duly enacted laws or policies of their co-nationals. Meanwhile, for those in the national minority, democratic procedures alone cannot mitigate the problem of disagreement. As we saw, those procedures presume that the boundary problem has already been solved for the people in question. To be sure, those in the national minority may still have access to regular NJT reasons. But, as we also saw earlier, NJT reasons underdetermine the scope of legitimate authority. Where NJT reasons run out (as they inevitably will), those in the national minority find themselves with only strategic reasons for obedience (as opposed to rational reasons for acceptance).

To be clear, I do not presume that members of the minority national group suffer any actual oppression at the hands of the majority (although this might also be the case). Rather, my point is that those in the national minority will be exposed to less legitimate authority and, consequently, more coercion at the hands of the state. Members of the national majority have several potential reasons for respecting the law: they may have standard NJT reasons, they may have reasons that derive from the interaction been nationality and democratic procedures, or they be moved by substantive commitments to

\footnotetext{
${ }^{6}$ This is not to deny that in some exceptional cases political ideology and nationality might be more closely tied. For example, for some Americans nationality may have a distinct ideological component (i.e. a commitment to liberal democracy or an opposition to socialism).
} 
justice. Each additional reason insulates members of the majority from the coercion that they might otherwise suffer. In contrast, those in the national minority have fewer reasons. Like everyone else, they may have NJT reasons to acknowledge certain areas of state authority. But what they do not have, quite obviously, is a reason to accept the law based on their national identification, a reason which they might otherwise fall back on when other reasons run dry.

Assuming then that one is going to be subject to political power, it is clearly better to be subject to a putative authority that one has sufficient reasons to treat as genuinely authoritative. Indeed, on the Razian view, legitimate authority is a service to us, it helps us act in accordance with reasons that already apply to us. The accommodation of minority national groups can therefore be justified in terms of how alternative arrangements to simple majoritarian democracy might provide for a more equitable distribution of legitimate authority in nationally divided societies. Just as standard democratic procedures allow members of a national majority to translate their sense of national identification into identification with authority, certain counter-majoritarian arrangements might allow minority nationalists to identify with political authority as their own.

The appropriate institutional remedies will vary according to context. In some cases, the obvious remedy is territorial self-government. Where a minority national group forms a majority within a particular self-governing region, members of the group can elect a government to enact laws and policies on their behalf. Thus, given sufficiently democratic procedures, members of the minority national group would have reasons of national identification to accept the authority of those laws and policies. The full extent to which such measures can ameliorate the problem of political authority for minority national groups would depend then on the extent of the self-governing region's jurisdiction. Practical considerations may still dictate which order of government is best situated to regulate those matters which involve relative expertise or technocratic coordination. But the argument here implies that, where possible, the self-governing region ought to enjoy primary jurisdiction over those matters that are most likely to turn on contested conceptions of the good and/or the right (e.g. healthcare, education, social welfare, etc.). In other cases, where the minority national group is territorially intermingled with the majority, consociational mechanisms (i.e. power-sharing and minority veto-power, etc.) will be the 
appropriate response. There the inclusion of all groups at the centre of political power, coupled with safeguards to prevent the domination of one group by the other, would allow those in the national minority to identify with the system of government as their own (albeit in a more qualified way than they would under territorial self-government). In any case, the scheme of accommodation will be justified in so far as it facilitates a more even distribution of legitimate authority.

\section{Conclusion}

I have argued here that, given a sufficiently democratic context, people who share a common nationality have genuine normative reasons to accept the putative authority of the law and government. However, standard majoritarian democracy will fail to give members of minority national groups comparable reasons to accept that putative authority. Special measures to accommodate minority nationalism can be justified then in so far as they may help to remedy this disadvantage.

A few final remarks about this argument are in order. First, although my argument is obviously indebted to Raz's theory of authority, my conclusions are probably not the conclusions Raz himself would come to. Raz has long recognized a role for reasons of identification where NJT reasons are inconclusive. But in a more recent restatement of his theory, Raz seems to suggest that NJT reasons (although variable and sometimes inconclusive) are nevertheless broad enough in scope to effectively defuse the problem of authority in nationally divided societies (Raz 2006, 1040-44); responding to the problem of "individuals or groups that do not and cannot bring themselves to identify with their country or to regard its government as their own” (Raz 2006, 1042), Raz explains that NJT reasons not only explain how and why the commands of a putative authority can be justified, "in the sense of being for the good" (Raz 2006, 1044), but also the conditions under which "it will be reasonable for its subjects to identify themselves with it" (Raz 2006, 1043). On this point Raz and I part ways. For reasons canvassed earlier, I doubt that many political decisions, say on social welfare or immigration, can be neatly collapsed into coordination problems or resolved, even hypothetically, by an appeal to an authority's superior expertise or moral wisdom. This deficiency can be overcome by democratic decision-making procedures for those in the national majority; as we have seen, they will 
typically have reasons of national identification to accept the outcomes of those procedures (even when NJT reasons run out). But members of minority national groups will have no such reasons unless the procedures in question are complemented by appropriate countermajoritarian mechanisms. Second, nothing I have said here should be taken as an argument for or against the secession of minority national groups; the question of a right to secede from existing states raises a series of philosophical, legal, and practical problems that go beyond the scope of the discussion here (see Buchanan 1997). In any case, secession will typically leave some members of the minority national group stranded in the original state while simultaneously creating new and vulnerable minorities out of once dominant majorities in the seceding territory (see Horowitz 1998). Consequently, even after secession, there may be good reasons to consider the accommodation of minority national groups. Finally, I have not addressed the moral question of how minorities might respond to the imposition of what is, according to my argument, illegitimate political authority. If one follows the argument here to its logical conclusions, there may well be circumstances in which minority national groups would be justified in disobeying or actively resisting the putative authority of the state.

Queen's University Belfast

School of Law

University Square

Belfast BT7 1NN

E-mail: a.schwartz@qub.ac.uk

\section{References}

Anderson, Benedict. 2006. Imagined Communities. Rev Edn. London: Verso.

Buchanan, Allen. 1997. Theories of Secession. Philosophy and Public Affairs 26: 31-61.

Brubaker, Rogers. 2004. In the Name of the Nation: Reflections on Nationalism and Patriotism. Citizenship Studies 8 (2): 115-27. 
Calhoun, Craig. 2007. Nations Matter: Culture, History, and the Cosmopolitan Dream. London: Routledge.

Christiano, Thomas. 2004. The Authority of Democracy. Journal of Political Philosophy 12(3): 266-90.

Darwall, Stephen. 2010. Authority and Reasons: Exclusionary and SecondPersonal. Ethics 120 (2): 257-78.

De-Shalit, Anver. 1996. National Self-determination: Political, not Cultural. Political Studies 44(5): 906-920.

Dworkin, Ronald. 1986. Law's Empire. Cambridge, MA: Harvard University Press, 1986.

Gellner, Ernest. 1983. Nations and Nationalism. Ithaca: Cornell University Press.

Gilbert, Margaret. 2006. A Theory of Political Obligation. Oxford: Oxford University Press.

Goodin, Robert. 2007. Enfranchising all Affected Interests, and its Alternatives. Philosophy and Public Affairs. 35 (1): 40-68.

Green, Leslie. 1988. The Authority of the State. Oxford: Clarendon Press.

Hershovitz, Scott. 2003. Legitimacy, Democracy, and Razian Authority. Legal Theory 9: 201-20;

Hershovitz, Scott. 2011. The Role of Authority. Philosopher's Imprint 11(7): 1-19. 
Horowitz, Donald. 1998. Self-Determination: Politics, Philosophy, and Law. In National Self-Determination and Secession. Ed. Margaret Moore. Oxford: Oxford University Press.

Horton, John. 1992. Political Obligation. London: Macmillan.

Keating, Michael. 2001. Plurinational Democracy: Stateless Nations in a PostSovereignty Era. Oxford: Oxford University Press.

Kymlicka, Will. 1995. Multicultural Citizenship: A Liberal Theory of Minority Rights. Oxford: Oxford University Press, 1995.

Margalit, Avishai and Joseph Raz. 1990. National Self-determination. The Journal of Philosophy 87 (9):439-461.

Martin, Margaret. 2010. Raz's The Morality of Freedom: Two Models of Authority. Jurisprudence 1: 63-84.

Miller, David. 1995. On Nationality. Oxford: Oxford University Press.

Miller, David. 2007. National Responsibility and Global Justice. Oxford: Oxford University Press.

Miller, David. 2009. Democracy's Domain. Philosophy and Public Affairs 37(3): 201-28.

Moore, Margaret. 1999. Beyond the cultural argument for liberal nationalism. Critical Review of International Social and Political Philosophy 2(3): 26-47

Moore, Margaret. 2001. The Ethics of Nationalism. Oxford: Oxford University Press.

Näsström, Sofia. 2007. The Legitimacy of the People. Political Theory 35(5): 624-658. 
Parfit, Derek. 1997. Reasons and Motivation. Supplement to the proceedings of The Aristotelian Society 71: 99-130.

Raz, Joseph. 1979. The Authority of Law. Oxford: Oxford University Press.

Raz, Joseph. 1984. The Obligation to Obey: Revision and Tradition. Notre Dame Journal of Law, Ethics \& Public Policy 1: 139-155.

Raz, Joseph. 1988. The Morality of Freedom. Oxford: Oxford University Press.

Raz, Joseph. 2006. The Problem of Authority: Revisiting the Service Conception. Minnesota Law Review 90: 1003-44.

Raz, Joseph. 2011. From Normativity to Responsibility. Oxford: Oxford University Press.

Rundle, Kristen. 2013. Form and Agency in Raz’s Legal Positivism. Law and Philosophy 32(6): 767-791.

Sadurski, Wojciech 2008. Legitimacy, Political Equality, and Majority Rule. Ratio Juris 21(1): 39-65.

Simmons, A. John. 1996. Associative Political Obligations. Ethics 106: 247-73.

Simmons, A. John. 2013. Democratic Authority and the Boundary Problem. Ratio Juris 26(3): 326-57.

Spinner-Halev, Jeff and Elizabeth Theiss-Morse. 2003. National Identity and Self-Esteem. Perspectives on Politics 1: 515-32.

Tamir, Yael. 1995. Liberal Nationalism. Princeton: Princeton University Press. 
Taylor, Charles. 1994. The Politics of Recognition. In Multiculturalism: examining the politics of recognition. Ed. Amy Gutmann. Princeton: Princeton University Press.

Tierney, Stephen. 2004. Constitutional Law and National Pluralism. Oxford: Oxford University Press.

van der Vossen, Bas. 2011. Associative Political Obligations. Philosophy Compass 6: 47787.

Waldron, Jeremy. 1995. Legislation, Authority, and Voting. Georgetown Law Journal 84: 2185-214.

Waldron, Jeremy. 2003. Authority for Officials. In Rights, Culture and the Law: Themes from the Legal and Political Philosophy of Joseph Raz. Eds. L.H. Meyer, S.L. Paulson, and T.W. Pogge. Oxford: Oxford University Press.

Whelan, Frederick G.. Prologue: democratic theory and the boundary problem. In Liberal Democracy. Eds. J. Roland Pennock and John W. Chapman. New York: New York University Press.

Yack, Bernard. 2001. Popular Sovereignty and Nationalism. Political Theory 29: 517-36.

Yack, Bernard. 2012. Nationalism and the Moral Psychology of Community. Chicago: University of Chicago Press. 